PACS: 02.70.Bf, 41.20.Jb, 41.20.-q

\title{
COMPUTATIONAL MODELING OF SAR AND HEAT DISTRIBUTION IN LOSSY MEDIUM AT GSM FREQUENCIES
}

\author{
Khitam Y. Elwasife \\ Department of Physics, College of Science, Islamic University, Gaza, Palestinian Territory \\ E-mail:kelwasife@iugaza.edu.ps \\ Received 1 November 2018, accepted 12 December 2018
}

\begin{abstract}
In recent years, institution has increased imposition of electromagnetic radiation in many applications. This radiation react with the human tissue and may lead to harmful and injurious effects on human health. However a finite difference thermal model of lossy medium as (spinal cord of human body) has been developed to calculate temperature rises generated in the spinal cord by radiation from cellular telephones with different frequencies. The natural metabolic heat production and the power density absorbed from the electromagnetic field have been evaluated. The specific absorption rate (SAR) was derived from a finite difference time domain model (FDTD) of the spinal cord. This is a numerical analysis is technique used for modeling computational electrodynamics. Aside from the specific absorption rate, through the exposure of radiation is an extremely important parameter while assessing the effects on spinal cord tissue. The heat distribution was calculated using the bioheat equation coupled with Maxwell's equation. A one dimensional finite difference time domain method has been used, some simulations for electromagnetic wave through the spinal cord tissue is made using software program. Also for the simulation, the dielectric properties supposed medium are directly taken by numerical program. Results show that electromagnetic fields penetrate the life tissues and attenuate fast to reach zero at large time steps. Specific absorption rate show maximum at the first boundary of tissue and becomes less value by using high frequency. The absorbent power and specific absorption rate show maximum at the interface of tissue, and the technique developed may be used to estimate temperature rises associated with specific absorption rate (SARs) for different types of radiation. Also, the results note that low-frequency waves have significantly affected the biological tissue.
\end{abstract}

KEY WORDS: global system mobile radiation, FDTD, spinal human body tissue, SAR

\section{КОМПЮТЕРНЕ МОДЕЛЮВАННЯ SАR ТА ТЕПЛОВОГО РОЗПОДІЛУ В СЕРЕДОВИЩАХ 3 ВТРАТАМИ НА GSM ЧACTOTAX \\ Khitam Y. Elwasife}

Фізичний факультет, Науковий коледж, Ісламський університет, Газа, Палестинська територія

В останні роки установи посилили використання електромагнітного випромінювання у багатьох областях застосування. Це випромінювання реагує з людською тканиною і може призвести до шкідливого та згубного впливу на здоров'я людини. Так було розроблено теплову модель середовища з втратами (спинного мозку людського тіла) для розрахунку підвищення температури, що виникає у спинному мозку, через випромінювання від стільникових телефонів різної частоти. Оцінено природне виникнення тепла від метаболізму та щільність електроенергії, при поглинанні енергії електромагнітного поля. Було отримано питомий коефіцієнт поглинання електромагнітної енергії (SAR) методом кінцевої різниці у часовій області (FDTD) спинного мозку. Це техніка чисельного аналізу, що використовується для комп'ютерного моделювання електродинаміки. Питома швидкість поглинання , при опроміненні $є$ надзвичайно важливим параметром при оцінці впливу на тканини спинного мозку. Розподіл тепла розраховувався за допомогою біоенергетичного рівняння, поєднаного з рівнянням Максвелла. Було використано одномірний метод кінцевих різниць у часовому домені, моделювання проходження електромагнітної хвилі через тканину спинного мозку яке виконано за допомогою комп'ютерної програми. Також для моделювання діелектричні властивості ймовірного середовища безпосередньо вводилися у програму. Результати показують, що електромагнітні поля проникають в живі тканини і швидко ослаблюються, і досягають нуля для великих інтервалах. Питома величина поглинання показує максимум на першій межі тканини і досягає меншого значення з підвищенням частоти. Величина поглинання та питома частота поглинання показують максимум на межі тканини, тож розроблена методика може бути використана для оцінки підвищення температури, пов'язаної з питомою швидкістю поглинання (SAR) для різних типів випромінювання. Крім того, відзначимо, що низькочастотні хвилі істотно впливають на біологічну тканину.

КЛЮЧОВІ СЛОВА: глобальна система мобільного випромінювання, FDTD, спинний мозок людини, SAR

The increasing use of mobile communication devices and base station, especially mobile phones by people, has been discussed in many research that is on whether there is a larger radio frequency energy absorption in the human heads. the temperature rises induced in the eye and lens by near-field exposure to radiation from communication handsets, using the finite difference time domain method and classical bioheat equation have been studied [1]. A mathematical simulation model of the head has been constructed [2]. Finite-difference time-domain method of the specific absorption rate have been calculated on this model. Using antenna which mounted either at the center or corner of the top face of the box. Choosing the frequencies as $900 \mathrm{MHz}$ and $1800 \mathrm{MHz}$. Three irradiation geometries were considered, a vertical handset in front of the eye and vertical and horizontal orientations at the side of the ear. Also the effect of a hand handset was considered. The results of the simulation model was also presented for a half-wavelength dipole. The specific absorption rate (SAR) in scaled human head models is also evaluated by study a differences between SAR in the heads of adults and children and for assessment of compliance with the international safety guidelines, while using a mobile phone. The finite-difference time-domain calculated has been used for calculating SAR values for models of both children and adults, 
at 900 and $1800 \mathrm{MHz}$ [3]. Another study was found that the analyses suggest of the SAR difference between adults and children is more likely caused by the general differences in the head anatomy and geometry of the individuals rather than age [4]. It clears that the external shape of the head and the distribution of different tissues within the head play a significant role in the radio frequency energy absorption.

The aim of paper is to evaluate the thermal effect of electromagnetic mobile phone radiations on spinal cord and specific absorption rate in life tissue.

\section{THEORY AND MODEL}

The spatial domain of the boundary value problem may be complicated in general, and the direct analytical solution of the problem is usually impossible. As a result, spatial and temporal discretization is employed for the approximate numerical solution of the problem. To this end, several approximate solution techniques have been developed so far, the most important ones being the Finite difference time domain Method (FDTD). At first to find the effects of a certain exposure to radiation in the human spinal cord, we determine the dielectric properties of human spinal cord at global system mobile frequency as $900 \mathrm{MHz}$ and $1.8 \mathrm{GHz}$ as in Table below, The dielectric properties of a life tissue are different according changing frequency $[5,6]$.

Table

Dielectric properties of spinal cord tissue at $900 \mathrm{MHz}$ and $1.8 \mathrm{GHz}$

\begin{tabular}{|c|c|c|c|c|c|c|c|c|c|}
\hline $\begin{array}{c}\text { Frequency } \\
{[\mathrm{Hz}]}\end{array}$ & $\mathrm{P}$ & $\mathrm{P}$ & $\begin{array}{c}\text { Specific } \\
\text { heat } \\
\text { (blood) } \\
\text { capacity } \\
\text { (spinal } \\
\text { cord) }\end{array}$ & $\begin{array}{c}\text { Blood } \\
\text { Specific } \\
\text { heat } \\
\text { capacity } \\
\mathrm{Cb}\end{array}$ & $\begin{array}{c}\text { Electrical } \\
\text { Conductivity } \\
{[\mathrm{S} / \mathrm{m}]}\end{array}$ & $\begin{array}{c}\text { Relative } \\
\text { permittivity }\end{array}$ & $\begin{array}{c}\text { Thermal } \\
\text { conductivity } \\
\mathrm{k}[\mathrm{W} / \mathrm{m} / \mathrm{k}]\end{array}$ & $\begin{array}{c}\text { Wavelength } \\
{[\mathrm{m}]}\end{array}$ & $\omega_{b}$ \\
\hline $900 \mathrm{MHz}$ & 1050 & 1075 & 3630 & 3770 & 0.57369 & 32.531 & 0.513 & 0.057543 & $4.36 \times 10^{-4}$ \\
\hline $1800 \mathrm{MHz}$ & 1050 & 1075 & 3630 & 3770 & 0.8429 & 30.867 & 0.513 & 0.029708 & $4.36 \times 10^{-4}$ \\
\hline
\end{tabular}

A one dimensional finite difference time domain method is used to solve bioheat transient and Maxwell's equations, the partial differential equations to yield the following difference equations [5]

$$
E_{x}^{n+\frac{1}{2}}(k)=\frac{1-\frac{\varphi_{2} \Delta t}{2 \varphi_{1}}}{1+\frac{\varphi_{2} \Delta t}{2 \varphi_{1}}} E_{x}^{n-\frac{1}{2}}(k)-\frac{\frac{\Delta t}{\Delta z \cdot \varphi_{1}}}{1+\frac{\varphi_{2} \Delta t}{2 \varphi_{1}}}\left[H_{y}^{n}\left(k+\frac{1}{2}\right)-H_{y}^{n}\left(k-\frac{1}{2}\right)\right] .
$$

Similarly the magnetic field becomes

$$
\left(H_{y}^{n+1 / 2}(k)-H_{y}^{n-1 / 2}(k)=\frac{\Delta t}{\Delta z \cdot \varphi_{3}}\left[E_{x}^{n}(k-1 / 2)-E_{x}^{n}(k+1 / 2)\right] .\right.
$$

And the bioheat equation solved as

$$
\begin{aligned}
& T^{n+1 / 2}(k)=\frac{\frac{-\Delta t}{p_{r} \Delta z^{2}}}{1-\frac{M}{2}+\frac{\lambda}{8}\left(E_{x}^{n+1 / 2}(k)-E_{x}^{n-1 / 2}(k)\right)}\left[T^{n}(k+1 / 2)-2 T^{n}(k)+T^{n}(k-1 / 2)\right]-, \\
& -M+\frac{M}{2}-\frac{\lambda}{8}\left[\left(E_{x}^{n+1 / 2}(k)-E_{x}^{n-1 / 2}(k)\right] T^{n-1 / 2}(k)\right. \\
& T^{n+1 / 2}(k)=\frac{-\Delta t}{1-\frac{M}{2}+\frac{\lambda}{8}\left(E_{x}^{n+1 / 2}(k)-E_{x}^{n-1 / 2}(k)\right)}\left[T^{n}(k+1 / 2)-2 T^{n}(k)+T^{n}(k-1 / 2)\right]- \\
& -M+\frac{M}{2}-\frac{\lambda}{8}\left[\left(E_{x}^{n+1 / 2}(k)-E_{x}^{n-1 / 2}(k)\right] T^{n-1 / 2}(k)\right.
\end{aligned}
$$


where $M=\omega_{1} \rho_{1} c, \omega_{1}$ is the mass flow rate of blood flow per unit volume (blood perfusion), thermal conductivity $\rho_{1}$, and heat capacity $c$ are assumed to be constants. E and $\mathrm{H}$ are electric and magnetic field respectively.

The parameters which we used in the software program to fine the heat diffusion in spinal tissue by simulation FDTD method are illustrated in the equations below:

$$
\begin{aligned}
& \varphi=\frac{L^{2} T_{b}^{m-1}|| E_{0}^{2} \mid}{v \rho c} \\
& \varphi_{1}=\frac{E_{0} v \varepsilon_{0}}{L H_{0}}, \quad \varphi_{2}=\frac{E_{0} L \sigma}{H_{0}}, \quad \varphi_{3} \frac{H_{0} v \mu_{0}}{L E_{0}}, \quad \rho_{1}=\frac{\rho b}{\rho}, \quad c=\frac{c_{b}}{c_{p}} \\
& \text { and } \omega_{1}=\frac{\omega_{b} L^{2}}{v}
\end{aligned}
$$

\section{RESULTS AND DISCUSSION}

FDTD method has been used for many applications including calculating SARs and induced currents in the human body etc. The electrical properties of various biological tissues, permittivity and conductivity are very important by SAR calculating. Permittivity and conductivity depend on frequency. Various parameters by SAR calculating with EMF from mobile phone are operational frequency and antenna power, mutual positions of the device and head design of the device and size of human head. In this work the comparison between heat distribution with different frequencies in human spinal cord and specific absorption rate also, have been evaluated. In Figure 1 it appear that at electric field in free space, the heat is very high compare with low electric field. Figure 2, heat distribution plotted against space coordinates for different magnetic field, but in this case the high value of heat distribution was obvious at low magnetic field.

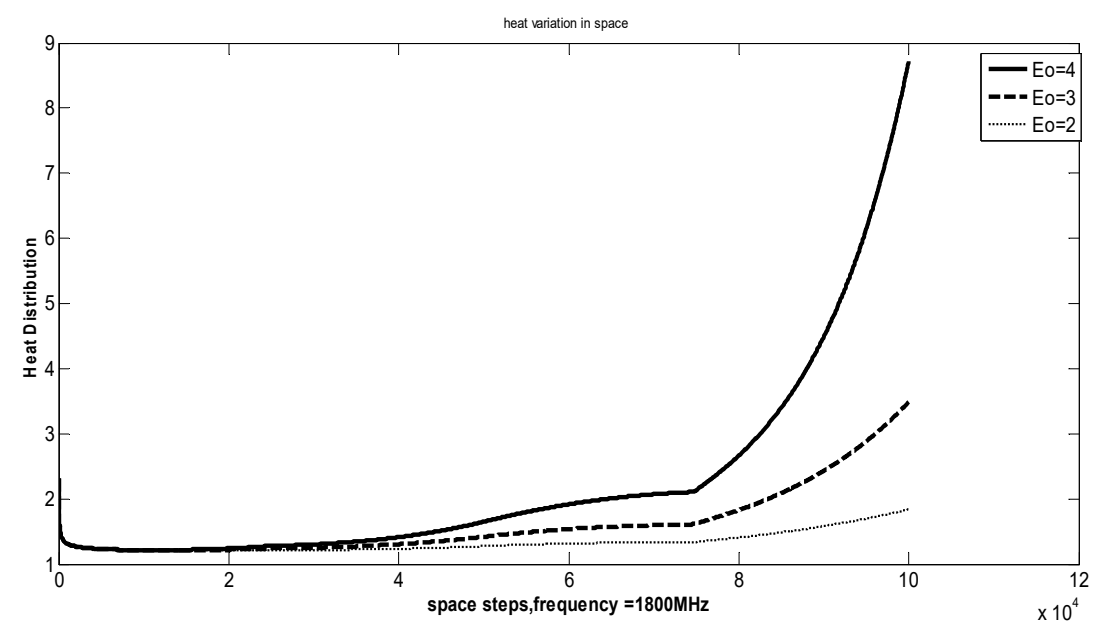

Fig. 1. Heat distribution plotted against space coordinates for different electric field where $c_{b}=3770, c_{p}=3630, \omega_{b}=0.00436, k=0.513, \rho($ spinal cord $)=1030, E_{0}=2,3, \rho_{p}=1050, L=0.002$, density of spinal cord is $1075 \mathrm{~kg} / \mathrm{m}$, frequency $=1.8 \mathrm{GHz}$

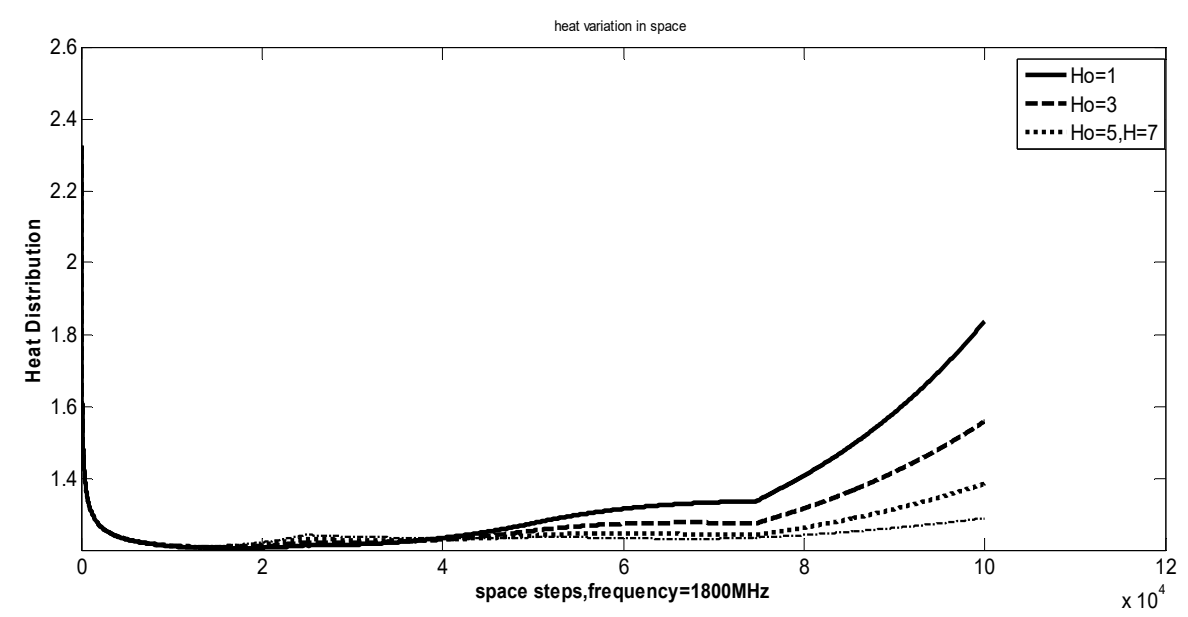

Fig. 2. Heat distribution plotted against space coordinates for different magnetic field where $c_{b}=3770, c_{p}=3630, \omega_{b}=0.00436, k=0.513, \rho($ spinal cord $)=1030, E_{0}=2(v / m) \rho_{p}=1050, L=0.002$, density of spinal cord is $1075 \mathrm{~kg} / \mathrm{m}$ 


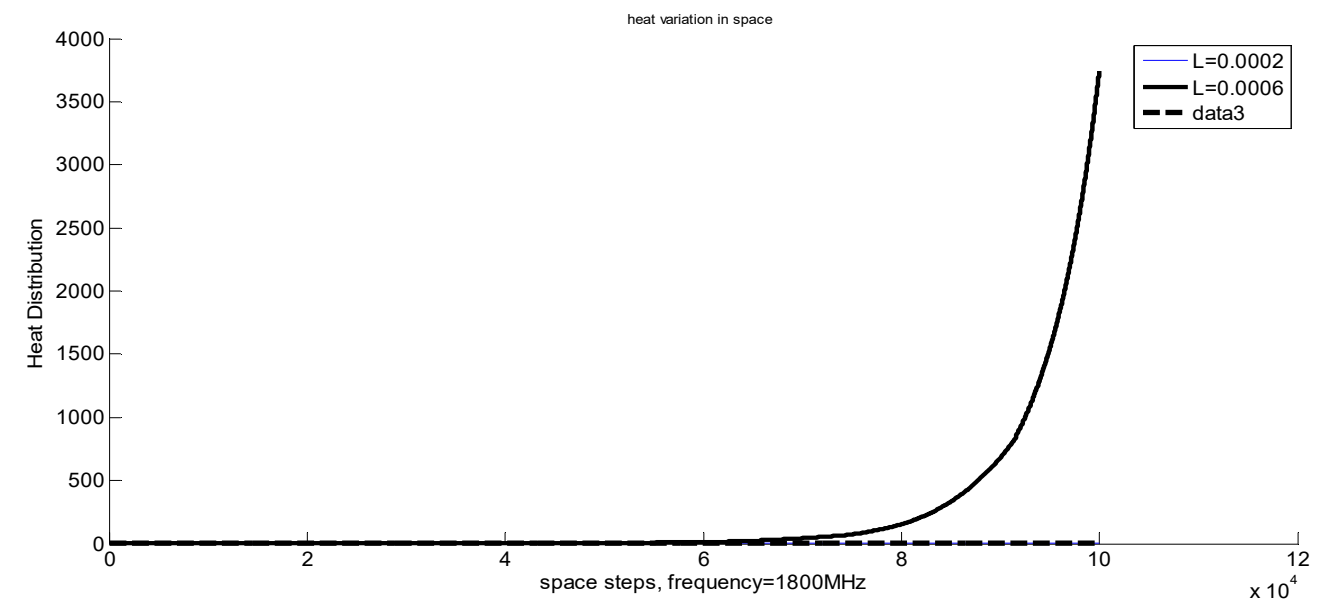

Fig. 3. The heat distribution plotted against space coordinates for different thickness

where $\mathrm{c}_{\mathrm{b}}=3770, \mathrm{c}_{\mathrm{p}}=3630, \omega_{\mathrm{b}}=0.00436, \mathrm{k}=0.513, \rho($ spinal cord $)=1030, \mathrm{E}_{0}=2(\mathrm{v} / \mathrm{m}), \rho \mathrm{p}=1050, \mathrm{Ho}=1$, density of spinal cord is $1075 \mathrm{~kg} / \mathrm{m}$

In Figure 3, the heat distribution plotted against space coordinates for different thickness and frequency is $100 \mathrm{MHz}$, its note that at high thickness the heat is high but at low thickness there is no effect.

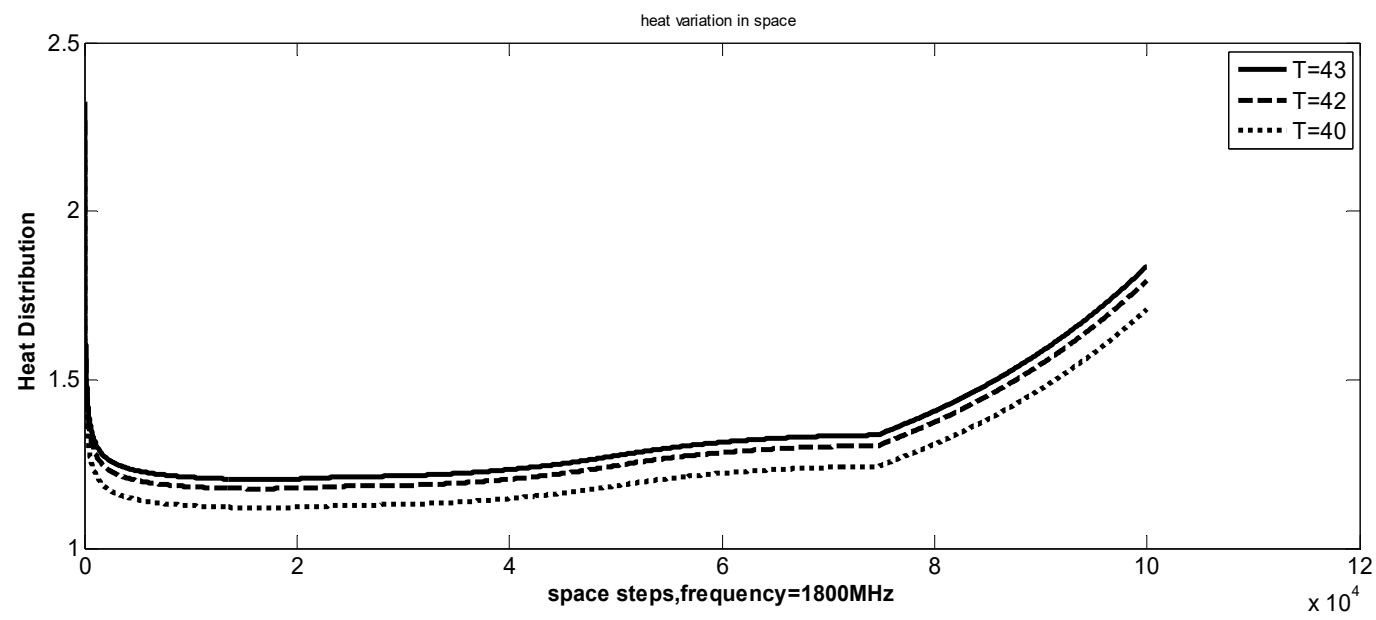

Fig. 4. The heat distribution plotted against space coordinates for different temperature

where $\mathrm{c}_{\mathrm{b}}=3770, \mathrm{c}_{\mathrm{p}}=3630, \omega_{\mathrm{b}}=0.00436, \mathrm{k}=0.513, \rho($ spinal cord $)=1030, \mathrm{E}_{0}=2(\mathrm{v} / \mathrm{m}), \mathrm{L}=0.002, \rho \mathrm{p}=1050, \mathrm{Ho}=1$, density of spinal cord is $1075 \mathrm{~kg} / \mathrm{m}$

Figure 4 illustrates the effect of three different values of transient temperature. It is shown that the heat distribution increases with increasing of temperature.

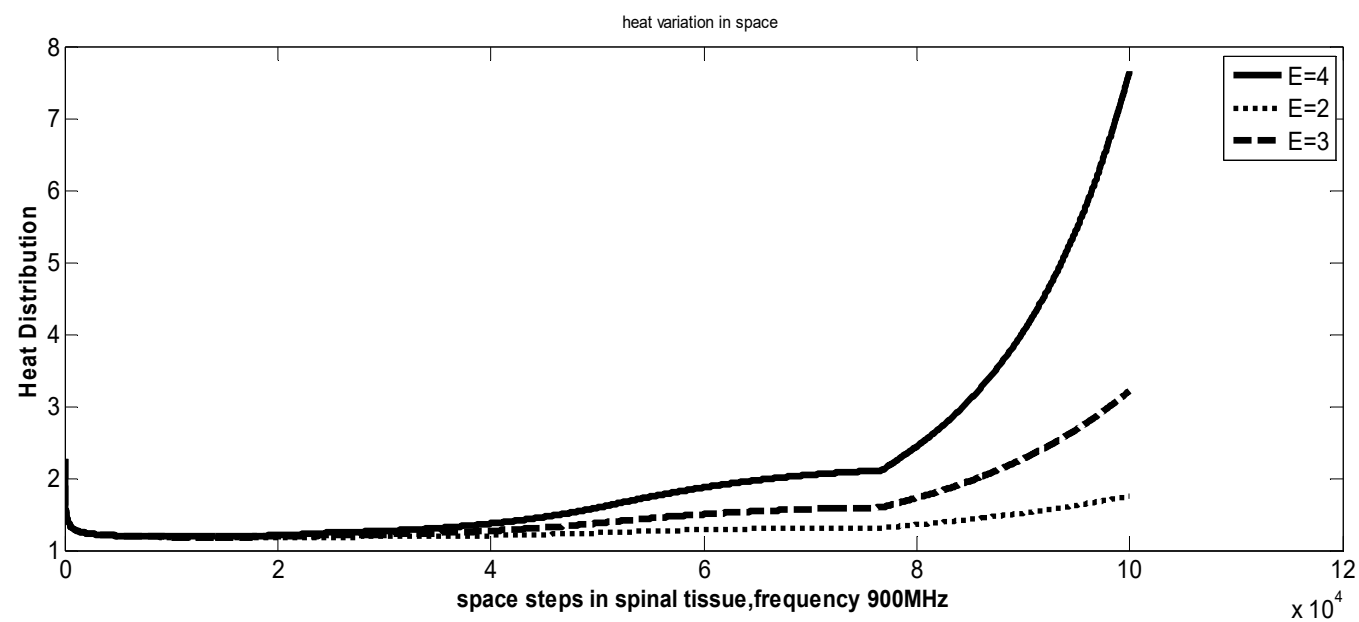

Fig. 5. Heat distribution plotted against space coordinates for different electric field

where $c_{b}=3770, c_{p}=3630, \omega_{b}=0.00436, k=0.513, \rho($ spinal cord $)=1030, E_{0}=2,3,4, \rho_{p}=1050, L=0.002$, density of spinal cord is $1075 \mathrm{~kg} / \mathrm{m}$, permittivity $=32.531$, frequency $=900 \mathrm{MHz}$ 
Also the heat is increasing for increasing the electric field in a high space step as shown in Figure 5. Furthermore, it shown that the heat distribution decreasing with increasing the magnetic field as in Figure 6 which that the heat distribution plotted against space coordinates for different magnetic field. The specific absorption rate change according the time steps as we noticed in Figure 7, the maximum first peak is at point $100 \mathrm{~W} / \mathrm{kg}$ after 300 time steps and frequency $900 \mathrm{MHz}$, it is obvious that the amplitude of specific absorption rate is different according the wave time travel through the spinal cord human tissue.

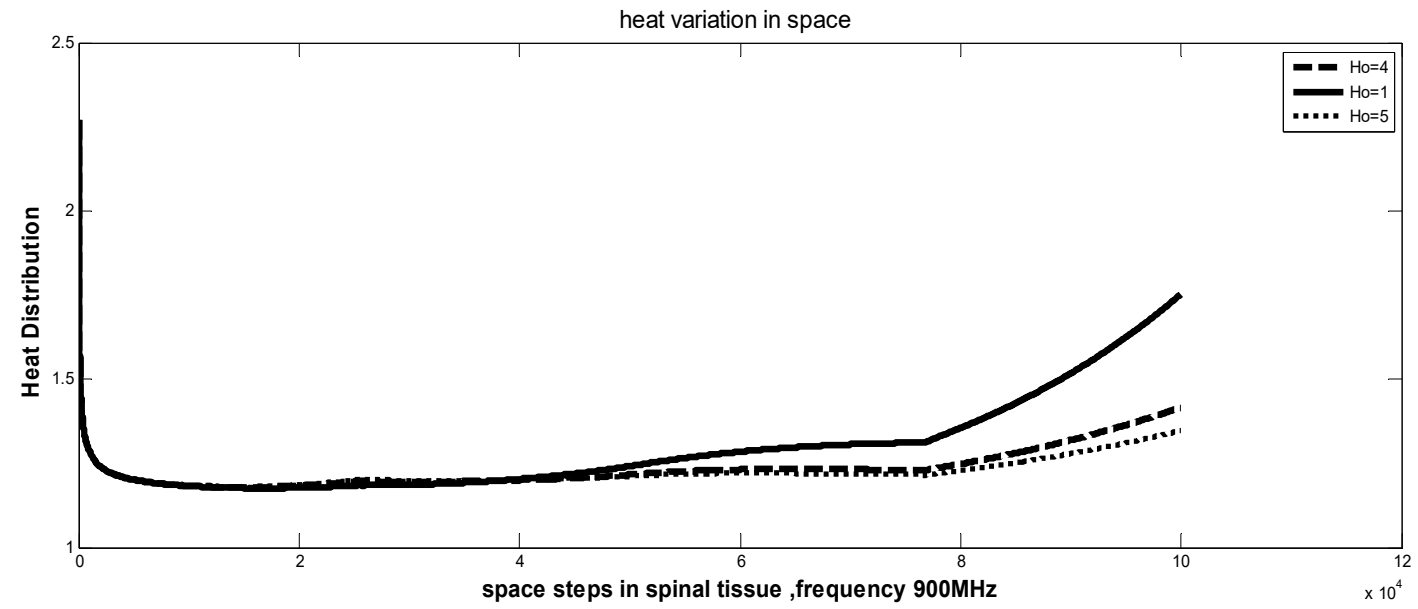

Fig. 6. Heat distribution plotted against space coordinates for different magnetic field $H=1, H=4, H=5$ where $c_{b}=3770, c_{p}=3630, \omega_{b}=0.00436, k=0.513, \rho($ spinal cord $)=1030, E_{0}=2(v / m), \rho_{p}=1050, L=0.002$ density of spinal cord is $1075 \mathrm{~kg} / \mathrm{m}$, frequency $=900 \mathrm{MHz}$

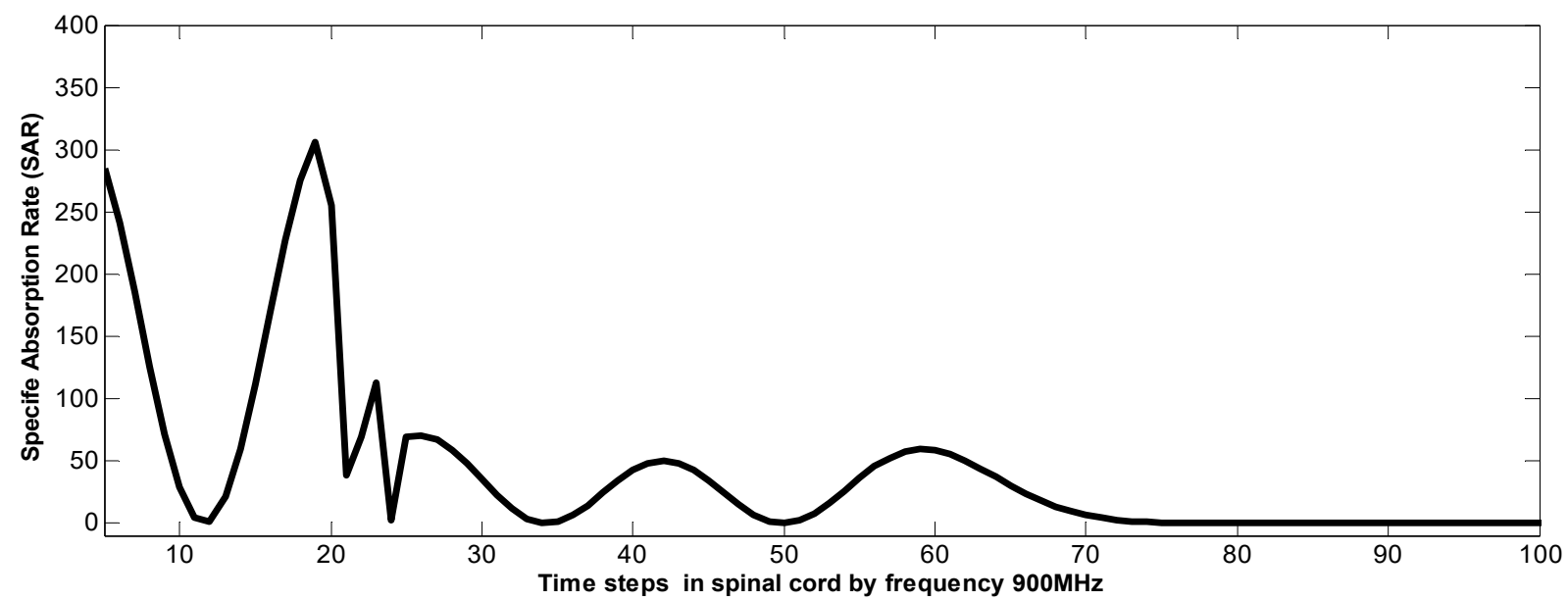

Fig. 7. Specific absorption rate distribution in spinal cord plotted vs time steps, frequency $=900 \mathrm{MHz}$

\section{CONCLUSION}

The temperature distributions for different thermal properties of tissue have been illustrated using numerical method as finite time domain method. Heat distribution plotted against space coordinates for different magnetic and electric fields, The applications of this work have necessary in many parts of science as cancer and therapy using microwave devices such as the thermocouple.

\section{ORCID IDs}

Khitam Y. Elwasife (iD) https://orcid.org/0000-0002-5386-0114

\section{REFERENCES}

[1]. M.J.M. Agustiño, J.M. Leiro, M.T.J. Mora, J.A. Rodriguez-Gonzalez, F.J.J. Barreiro, F.J. Ares-Pena and E. López-Martín, Biology open. 9, 831-838 (2012).

[2]. P.J. Dimbylow and S.M. Mann, Phys. in Medicine \& Biology. 10, 1537 (1994).

[3]. M. Martinez-Burdalo, A. Martín, M. Anguiano and R. Villar, Phys. in Medicine \& Biology. 45, 345 (2004).

[4]. R. Huber, J. Schuderer, T. Graf, K. Jütz, A.A. Borbély, N. Kuster and P. Achermann, Bioelectromagnetics. 24, 262 (2003).

[5]. Kh. Elwasife, Int. J. of Pure \& Applied Sciences \& Technology. 10, 44 (2012).

[6]. Kh. Elwasife, Rom. J. Biophys. 28, 1 (2018). 